\title{
Antibody-Mediated Resistance to Rhizomania Disease in Sugar Beet Hairy Roots
}

\author{
M. Jafarzade ${ }^{1}$, M. Ramezani ${ }^{1}$, F. Hedayati ${ }^{1}$, Z. Mokhtarzade ${ }^{1}$, B. Zare $^{1}$, M. S. Sabet ${ }^{2}$, P. Norouzi ${ }^{3}$, and \\ M. A. Malboobi ${ }^{1 *}$ \\ ${ }^{1}$ Department of Plant Biotechnology, National Institute of Genetic Engineering and Biotechnology, Tehran 14965-161, \\ Iran \\ ${ }^{2}$ Department of Agriculture, Tarbiat Modares University, Tehran 14115-336, Iran \\ ${ }^{3}$ Sugar Beet Seed Institute, Agricultural Research, Education and Extension Organization (AREEO), Karaj 31585-4114, \\ Iran
}

(Received on June 17, 2018; Revised on August 31, 2018; Accepted on October 1, 2018)

Agrobacterium rhizogenes-mediated transformation of sugar beet hairy roots expressing single-chain variable fragment ( $\mathrm{scFv}$ ) was exploited to evaluate the efficacy of four antibody-based constructs for interfering with the Beet necrotic yellow vein virus infection. The $\mathrm{scFv}$ specific to a major coat protein of virus, p21, was targeted to various cellular compartments including the cytosol (pIC and pICC constructs), apoplast (pIA), and mitochondrion (pIM). After mechanical virus inoculation, most of the hairy root clones expressing $\mathrm{scFv}$ in the cytosol displayed low virus titers while the majority of transgenic hairy root clones accumulated antibody in outer membrane of mitochondria or apoplast were infected. This hairy root system provided an efficient and rapid approach to initially investigating root disease resistance like rhizomania prior to transform whole recalcitrant plants such as sugar beet.

Keywords : Agrobacterium rhizogenes, Beta vulgaris, BNYVV, rhizomania, scFv

Handling Editor : Lee, Yong Hoon

\footnotetext{
*Corresponding author.

Phone)+98-2144787325, FAX) +98-2144787395

E-mail)malboobi@nigeb.ac.ir, alimalboobi@gmail.com

(c) This is an Open Access article distributed under the terms of the Creative Commons Attribution Non-Commercial License (http:// creativecommons.org/licenses/by-nc/4.0) which permits unrestricted noncommercial use, distribution, and reproduction in any medium, provided the original work is properly cited.
}

Articles can be freely viewed online at www.ppjonline.org.
Rhizomania, which is the most damaging sugar beet diseases is caused by Beet necrotic yellow vein virus (BNYVV). The virus is vectored by soil-borne root infecting parasite Polymyxa betae Keskin with resting spores that last many years in the soil. The remarkable economic losses in sugar beet crops could happen as a consequence of significant decrease in root yield and sugar content (Asher and Blunt, 1987). Rhizomania was first documented in Italy more than half a century ago. It has now spread to almost all major sugar beet growing areas throughout the world. The use of resistant varieties is the only means to ensure profitable yield on BNYVV-infested soils. So far, such resistance is mainly conferred by dominant $R z 1$ and $R z 2$ genes. Recently, broken $R z$-based resistance against BNYVV has been reported in some regions (for a review see Tamada et al., 2016). The reported resistance-breaking isolates and high virulent pathotype of BNYVV mandate the needs for new sources of resistance (McGrann et al., 2009). Consequently, the use of transgenic plants offers an alternative approach to overcome BNYVV infection. Recently, RNA silencing has most been employed to enhance rhizomania resistance (Lennefors et al., 2006; Pavli et al., 2010; Zare et al., 2015). Similarly, recombinant antibodies, especially those with single-chain variable fragment ( $\mathrm{scFv}$ ), have been expressed in transgenic plants to manage viral infections mostly in model plants, Nicotiana tabacum and Nicotiana benthamiana (for a review see Safarnejad et al., 2011). There are a few studies conducted against serious viral diseases affecting economically important crops. Cervera et al. (2010) produced transgenic Mexican limes resistant to Citrus tristeza virus by expressing anti-CP scFv. Potato transgenic plant expressing scFvs against viral proteins NIa 
and $\mathrm{P} 1$, conferred resistance to Potato virus $Y$ (Ayadi et al., 2012; Bouaziz et al., 2009; Gargouri-Bouzid et al., 2006) and Potato leafroll virus (Nickel et al., 2008). Ghannam et al. (2015) described transient expression of nanobodies derived from camelid heavy chain antibodies confer resistance against Broad been mottle in Vicia faba. Nba specific to Grapevine fanleaf virus neutralize virus at an early step of infection in grapevine (Hemmer et al., 2018).

Plantibody approach was also exploited through expression of scFvs specific for the $\mathrm{CP}$ and the nonstructural protein p25 of BNYVV in N. benthamiana plants. Transgenic plants producing $\mathrm{CP}$-specific $\mathrm{scFv}$ in the endoplasmic reticulum showed delayed disease symptoms (Fecker et al., 1997)

We have already demonstrated the engineering of $\mathrm{scFv}$ antibody that specifically recognizes BNYVV CP in $N$. benthamiana plants that was targeted to different subcellular compartments, cytosol, apoplast, and mitochondria. The resultant transgenic events displayed high levels of resistance against rhizomania (unpublished data). The aim of this was to explore possible levels of protection against BNYVV through plantibody-based approach in an easily maintained transformed hairy root system of the target crop. In this system, the effectiveness of scFv fusion proteins directed to various cellular locations could be readily determined before going through tedious transformation of whole recalcitrant sugar beet plant.

Sugar beet seeds of O-type SBSI-02 diploid monogerm cultivar were provided by Sugar Beet Seed Institute of Iran. Agrobacterium rhizogenes strain AR15834 harboring plasmid pRi 15834 was used to transform sugar beet explants. Expression vectors pIA, pIC, pICC, pIM targeting scFv to apoplast, cytosol, cytosol, and mitochondrial membrane, respectively, were utilized (Fig. 1A).

These plasmids were introduced into A. rhizogenes cells as described by (Holsters et al., 1978). Bacteria were grown at $28^{\circ} \mathrm{C}$ in $10-\mathrm{ml} \mathrm{LB}$ medium containing rifampicin $(50 \mu \mathrm{g} / \mathrm{ml})$, spectinomycine $(100 \mu \mathrm{g} / \mathrm{ml})$, and kanamycin $(50 \mu \mathrm{g} / \mathrm{ml})$ to an $\mathrm{OD}_{600}=1.0$. Following centrifugation, the bacterial cells were resuspended in half strange liquid MS medium $(1 / 2 \mathrm{MS})$ medium containing $100 \mu \mathrm{g} / \mathrm{ml}$ acetosyringone. The bacterial suspension was adjusted to a final $\mathrm{OD}_{600}$ of 0.2 for transformation of in vitro cultured sugar beet petiole and leaf. The explants were cut into small pieces at about $2-3 \mathrm{~cm}$ and inoculated with the bacterial suspension for $10 \mathrm{~min}$, blotted dry and then transferred onto $1 / 2$ MS supplemented with the $100 \mu \mathrm{M}$ acetosyringone and 60 $\mu \mathrm{M} \mathrm{AgNO}{ }_{3}$ for $48 \mathrm{~h}$ in dark at $25^{\circ} \mathrm{C}$. After co-cultivation, Explants were transferred onto solid 1/2 MS supplemented with $250 \mathrm{mg} / \mathrm{l}$ cefotaxime and $50 \mathrm{mg} / \mathrm{l} \mathrm{kanamycin} \mathrm{and} \mathrm{in-}$
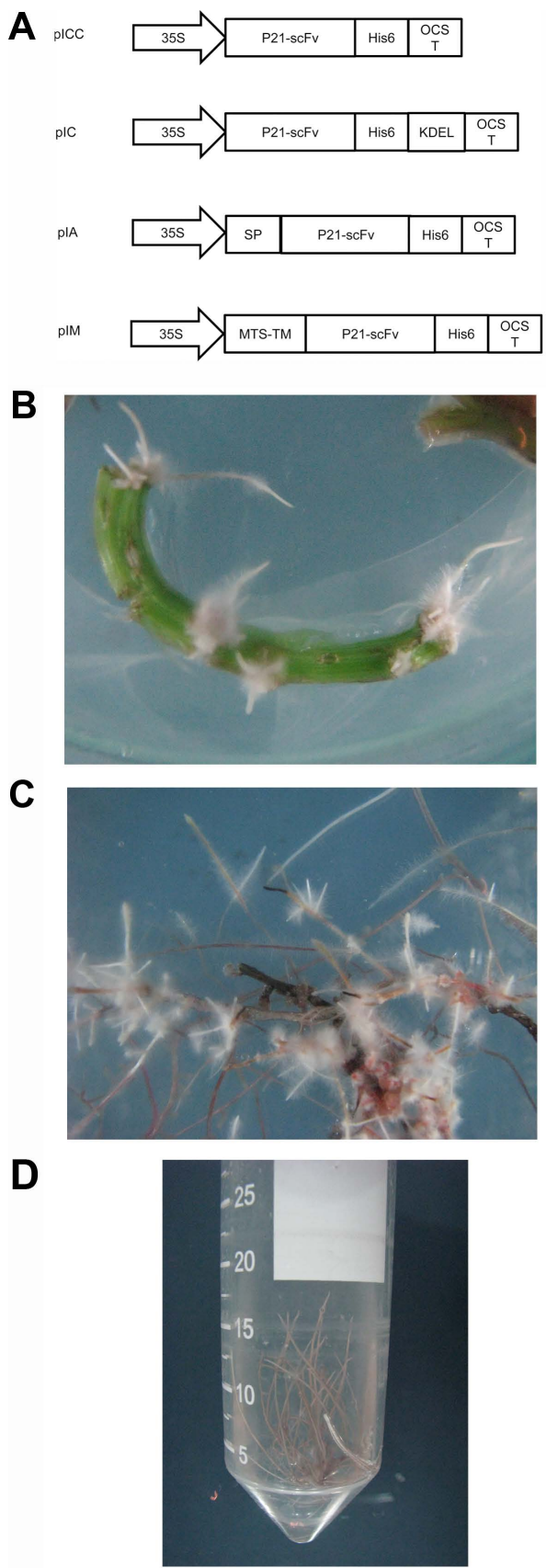

Fig. 1. Gene cassettes for engineered single-chain antibody fragments (scFv) expression in various cellular locations in Beta vulgaris hairy roots (A). Plant expression vectors pIC and pICC targeting $\mathrm{ScFv}$ to cytosol while pIA and pIM directing it to apoplast and cytoplasmic membrane of mitochondria, respectively. $35 \mathrm{~S}$, Cauliflower mosaic virus $35 \mathrm{~S}$ promoter; OCST, octopin synthase terminator; SP, polygalacturonase-inhibiting protein signal peptide; KDEL, endoplasmic reticulum retention signal to stabilize scFv in cytoplasm; MTS-TM, mitochondrial targeting sequence and transmembrane regions; His6, a six histidine tag. Hairy roots transformed with the $\mathrm{p} 21-\mathrm{scFv}$ gene 2 weeks after inoculation with Agrobacterium rhizogenes (B) and clonal hairy root cultures (C, D). 
cubated at $25^{\circ} \mathrm{C}$ and $16-\mathrm{h}$ photoperiod. Single hairy roots with $2-5 \mathrm{~cm}$ in size were excised and cultured in liquid $1 / 2$ MS medium containing $250 \mathrm{mg} / \mathrm{l}$ cefotaxime. The cultures were agitated at $120 \mathrm{rpm}$ on rotary shaker at $25^{\circ} \mathrm{C}$ and $16-\mathrm{h}$ photoperiod and subcultured every 15 days.

Genomic DNA was extracted from hairy roots based on the mini-Dellaporta method (Weigel and Glazebrook, 2009). Genomic integration of transgenes was confirmed by PCR using $\mathrm{scFv}$ specific primer pairs. PCR reaction was carried out with an initial cycle at $94^{\circ} \mathrm{C}$ for $5 \mathrm{~min}$; followed by 40 cycles at $94^{\circ} \mathrm{C}$ for $30 \mathrm{~s}, 64^{\circ} \mathrm{C}$ for $30 \mathrm{~s}, 72^{\circ} \mathrm{C}$ for $1-2$ min and a final cycle at $72^{\circ} \mathrm{C}$ for $10 \mathrm{~min}$. The PCR products were visualized by electrophoresis on $1 \%$ agarose gel. PCR-positive plants were evaluated for viral resistance as below. Accumulation of scFv in transgenic hairy roots was analyzed by western blotting using antibody against polyHis tail. For protein extraction, $1 \mathrm{~g}$ hairy roots were ground in liquid nitrogen to a fine powder. Total soluble protein (TSP) was obtained by using $0.5 \mathrm{ml}$ extraction buffer containing $100 \mathrm{mM}$ Tris- $\mathrm{HCl}(\mathrm{pH} 7.4), 500 \mathrm{mM} \mathrm{NaCl}, 5 \mathrm{mM}$ EDTA, $5 \mathrm{mM}$ dithiothreitol, $0.25 \mathrm{mM}$ phenylmethanesulfonylfluoride, and 5\% $\beta$-mercaptoethanol. Cell debris was separated by centrifuging at $10,000 \times g$ for $30 \mathrm{~min}$ at $4^{\circ} \mathrm{C}$. Quantification of TSP was carried out using Bradford method (Bradford, 1976). Fifty micrograms of TSPs were separated by $12 \%$ sodium dodecyl sulfate-polyacrylamide gel electrophoresis and then blotted onto PVDF membrane (Roche, Mannheim, Germany). The membrane was hybridized to Penta-His MAb (Qiagen, Hilden, Germany) followed by detection reactions using a horseradish peroxidase conjugated goat anti-mouse IgG (Jackson ImmunoResearch, West Grove, PA, USA) and ECL Western Blotting Detection Kit (Amersham, Munich, Germany).

Inoculum was produced from roots of sugar beet which were heavily infected with BNYVV. Infected roots were surface sterilized in $70 \%$ ethanol for $1 \mathrm{~min}$, then kept in $2.5 \%$ sodium hypochlorite solution plus one drop of Tween 20 for $30 \mathrm{~min}$ by continuous shaking and finally rinsed five times with sterile distilled water. The sterilized roots were kept on 1/2 MS medium for a month to be sure is free of infection.

The roots $(1: 3 \mathrm{w} / \mathrm{v})$ were triturated in $0.1 \mathrm{M}$ phosphate buffer $\mathrm{pH}$ 7.4. Inoculation was performed by adding $1-2 \mathrm{ml}$ sap together with $90 \mathrm{mg}$ carborundum into test tubes (150$\mathrm{mm}$ width) containing the hairy roots and then vortexed for $30 \mathrm{~s}$. Following agitation for at least 3-5 h, roots along with the infected sap were transferred into test tubes $(500 \mathrm{~mm}$ width) containing $10 \mathrm{ml} \mathrm{1/2} \mathrm{MS} \mathrm{medium.} \mathrm{For} \mathrm{assessment}$ of disease resistance in hairy roots, virus content was determined by double antibody sandwich enzyme-linked immunosorbent assay (DAS-ELISA) method (Clark and Adams, 1977) after 2 months. Sugar beet explants transformed by wild type AR15834 Agrobacterium cells served as negative controls, while the BNYVV-challenged ones served as positive controls

In order to evaluate the potential of antibody-based resistance to control rhizomania disease and comparing the possible effect of scFv accumulation in different cellular compartments, sugar beet hairy root system was found reliable. The binary vectors named A (pIA), M (pIM), C (pIC), and CC (pICC) (Fig. 1A) were transferred to sugar beet cells by exposure to $A$. rhizogenes. As a control, $A$. rhizogenesis harboring no binary vector was used to transform sugar beet. Hairy roots appeared on explants 14 days after inoculation (Fig. 1B). Single root events which were subsequently separated and subcultured in liquid 1/2 MS medium gave rise to clonal hairy root cultures (Fig. 1C and D). To confirm that $\mathrm{p} 21-\mathrm{scFv}$ gene transfer into hairy roots, PCR with gene specific primers was performed. The PCR products with expected size were observed in most hairy

Table 1. The rates of transgenic events resisted against viral infection

\begin{tabular}{lccc}
$\begin{array}{l}\text { Transferred } \\
\text { construct }\end{array}$ & Targeting compartment & $\begin{array}{c}\text { No. of infected plants } \\
\text { total plants }\end{array}$ & $\begin{array}{c}\text { Rate of immunization } \\
(\%)\end{array}$ \\
\hline pICC & Cytosol & $1 / 8$ & 87.5 \\
pIC & Cytosol & $2 / 10$ & 80 \\
pIA & Apoplast & $5 / 7$ & 28.5 \\
pIM & Mitochondrial outer membrane & $6 / 8$ & 25 \\
Positive control & - & $8 / 9$ & 11 \\
Negative control & - & $10 / 10$ & NA \\
\hline
\end{tabular}

Seven to 10 events for each transformant were challenged with Beet necrotic yellow vein virus (BNYVV) for 2 months. Viral infection was estimated by double antibody sandwich enzyme-linked immunosorbent assay method. Hairy roots derived from the cells transformed with wild type Agrobacterium rhizogenes and challenged with BNYVV served as positive control whereas the same hairy roots with no exposer to BNYVV used as negative controls. The cut off value was considered three standard deviations above the mean values of the negative controls.

NA, not applicable. 
roots that examined.

Seven to 10 PCR-positive hairy root events for each construct as well as the control hairy roots were involved in the bioassay experiments. Eight weeks after inoculation, virus titers were assessed by DAS-ELISA method. Out of nine wild type hairy roots challenged with BNYVV inoculum, eight hairy roots were infected whereas only 1 or 2 out of clonal hairy root harboring $\mathrm{CC}$ and $\mathrm{C}$ constructs were found positive for BNYVV infection. The least percentages of resistant hairy roots were obtained for transformants carrying $\mathrm{M}$ construct followed by A one (Table 1).

Expression levels of $\mathrm{scFv}$ in transgenic hairy roots were determined by western blot analysis. CC39, CC3, C28, $\mathrm{C} 10, \mathrm{M} 14$ hairy root clones showed the scFv protein band of $35 \mathrm{kDa}$. They are also resistant to virus whereas M10 and A35 which found infected, did not accumulate detectable amounts of scFv.

In another investigation, we expressed $\mathrm{scFv}$ against coat protein of BNYVV in various subcellular compartments of $N$. benthamiana plants which led to improved resistance to viral infection (unpublished data). We did not find any significant difference among resistance rates produced by scFvs targeted to either cytosol, apoplast or mitochondrial outer membrane. Here, we chose hairy root system developed through $A$. rhizogenes-mediated transformation to examine the effectiveness of different cellular constructs in hairy roots originated from sugar beet as a system closer to the targeted plant. Transgenic sugar beet roots directing $\mathrm{scFv}$ to the cytosol ( $\mathrm{C}$ and $\mathrm{CC}$ roots) confer stronger resistance to virus than to the mitochondrium or apoplastic scFv.

Cytosol is a desirable place for accumulation of recombinant antibodies against viruses where the virus uncoats, replicates and assembles. On the other hand, stability of antibodies in the cytosol has been questioned due to inappropriate folding in reducing environment of cytosol. However, antibody-based resistance has been obtained even at low expression levels of cytosolic scFvs (Tavladoraki et al., 1993; Zimmermann et al., 1998). Some strategies have also been reported to overcome the instability of cytosolic expressed scFvs; for instance, inclusion of a C-terminal KDEL or other short polypeptides or construction of more stable and functional antibodies through phage display technology (De Jaeger et al., 1999; Jahromi et al., 2009; Prins et al., 2005; Schouten et al., 1996, 1997; Spiegel et al., 1999; Villani et al., 2005; Yajima et al., 2010). In our experience, both $\mathrm{C}$ and $\mathrm{CC}$ hairy roots targeting scFv to the cytosol with or without KDEL respectively, exhibited resistance against BNYVV (Table 1). Two events carrying either of these constructs, $\mathrm{CC} 39$ and $\mathrm{CC} 3$ or $\mathrm{C} 10$ and

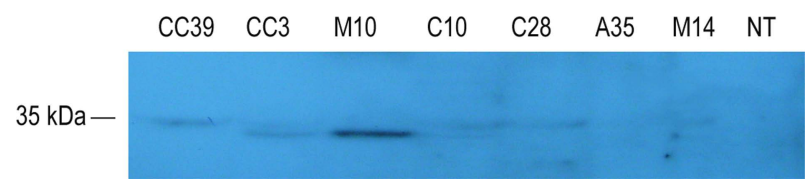

Fig. 2. Western blot detection of p21-scFv in transgenic events CC39, CC3, M10, C10, C28, A35, M14, and wild type 15835 Agrobacterium rhizogenes transformed plant (NT). Fifty micrograms total soluble proteins extracted from transgenic hairy roots were separated on $12 \%$ sodium dodecyl sulfate-polyacrylamide gel electrophoresis and blotted on PVDF membrane. The scFv proteins detected by Penta-His monoclonal antibody followed by a horseradish peroxidase-conjugated goat anti-mouse IgG.

C28, examined for scFV expression through western blotting (Fig. 2). No difference in expression level could detect among the examined events.

We have also targeted scFv to mitochondrial outer membrane where assambly of virus might happen. BNYVV particles have been shown to associate with cytoplasmic side of mitochondria at the early stages of infection. Subsequently, virons release from mitochondria and cluster into semiordered arrangements in the cytoplasm (Erhardt et al., 2001; Valentin et al., 2005). We assumed targeting p21-scFv to mitochondrion could interfere with BNYVV at an early stage of infection as it demonstrated an appropriate viral inhibition in $N$. benthamiana plants expressed $\mathrm{scFv}$ at mitochondrial outer membrane (unpublished data). Here, six out of eight different hairy root clones expressing mitochondrial $\mathrm{scFv}$ were positive to BNYVV propagation showing a rate of $25 \%$ resistance. Similarly, low rate of immunization was observed when scFV was targeted to apolplast where it may interfere with viral traffic.

An association between $\mathrm{scFv}$ detection and resistance to BNYVV was observed since scFv expressing hairy root events exhibited some virus inhibition. The lowest rates of viral inhibition obtained for mitochondrial and apoplastic expressed scFv. This is not consistent with our previous finding in tobacco plants (unpublished data). Differences in viral propagation and transmission in $N$. benthamiana and hairy roots of sugar beet plants could be a reason. However, insufficient number of challenged events to circumvent transgene positional effects could be the cause, as well.

In conclusion, our data suggest that expressed $\mathrm{scFv}$ directed against viral $\mathrm{CP}$ led to efficient resistance against the virus in transgenic sugar beet hairy roots as the natural host of the BNYVV. We have used a hairy root system prone to BNYVV mechanical infection successfully. This system allowed assessment of subcellular accumulation of scFv on the inhibition of the viral propagation. 


\section{Acknowledgments}

We are grateful to Dr. Mehdi Arbabi for kindly providing single-chain variable fragment specific to major coat protein of BNYVV.

\section{References}

Asher, M. J. C. and Blunt, S. J. 1987. The ecological requirements of Polymyxa betae. In: Proceedings of the 50th Winter Congress of the International Institute for Sugar Beet Research, pp. 45-55. Brussels, Belgium.

Ayadi, M., Bouaziz, D., Nouri-Ellouz, O., Rouis, S., Drira, N. and Gargouri-Bouzid, R. 2012. Efficient resistance to Potato virus $\mathrm{Y}$ infection conferred by cytosolic expression of anti-viral protease single-chain variable fragment antibody in transgenic potato plants. J. Plant Pathol. 94:561-569.

Bouaziz, D., Ayadi, M., Bidani, A., Rouis, S., Nouri-Ellouz, O., Jellouli, R., Drira, N. and Gargouri-Bouzid, R. 2009. A stable cytosolic expression of $\mathrm{VH}$ antibody fragment directed against PVY NIa protein in transgenic potato plant confers partial protection against the virus. Plant Sci. 176:489-496.

Bradford, M. M. 1976. A rapid and sensitive method for the quantitation of microgram quantities of protein utilizing the principle of protein-dye binding. Anal. Biochem. 72:248-254.

Cervera, M., Esteban, O., Gil, M., Gorris, M. T., Martínez, M. C., Peña, L. and Cambra, M. 2010. Transgenic expression in citrus of single-chain antibody fragments specific to Citrus tristeza virus confers virus resistance. Transgenic Res. 19:1001-1015.

Clark, M. F. and Adams, A. N. 1977. Characteristics of the microplate method of enzyme-linked immunosorbent assay for the detection of plant viruses. J. Gen. Virol. 34:475-483.

De Jaeger, G., Buys, E., Eeckhout, D., De Wilde, C., Jacobs, A., Kapila, J., Angenon, G., Van Montagu, M., Gerats, T. and Depicker, A. 1999. High level accumulation of single-chain variable fragments in the cytosol of transgenic Petunia hybrida. Eur. J. Biochem. 259:426-434.

Erhardt, M., Dunoyer, P., Guilley, H., Richards, K., Jonard, G. and Bouzoubaa, S. 2001. Beet necrotic yellow vein virus particles localize to mitochondria during infection. Virology 286:256-262.

Fecker, L. F., Koenig, R. and Obermeier, C. 1997. Nicotiana benthamiana plants expressing beet necrotic yellowvein virus (BNYVV) coat protein-specific $\mathrm{scFv}$ are partiallyprotected against the establishment of the virus inthe early stages of infection and its pathogenic effectsin the late stages of infection. Arch. Virol. 142:1857-1863.

Gargouri-Bouzid, R., Jaoua, L., Rouis, S., Saïdi, M. N., Bouaziz, D. and Ellouz, R. 2006. PVY-resistant transgenic potato plants expressing an anti-NIa protein scFv antibody. Mol. Biotechnol. 33:133-140.

Ghannam, A., Kumari, S., Muyldermans, S. and Abbady, A. Q.
2015. Camelid nanobodies with high affinity for broad bean mottle virus: a possible promising tool to immunomodulate plant resistance against viruses. Plant Mol. Biol. 87:355-369.

Hemmer, C., Djennane, S., Ackerer, L., Hleibieh, K., Marmonier, A., Gersch, S., Garcia, S., Vigne, E., Komar, V., Perrin, M., Gertz, C., Belval, L., Berthold, F., Monsion, B., SchmittKeichinger, C., Lemaire, O., Lorber, B., Gutiérrez, C., Muyldermans, S., Demangeat, G. and Ritzenthaler, C. 2018. Nanobody-mediated resistance to Grapevine fanleaf virus in plants. Plant Biotechnol. J. 16:660-671.

Holsters, M., De Waele, D., Depicker, A., Messens, E., Van Montagu, M. and Schell, J. 1978. Transfection and transformation of Agrobacterium tumefaciens. Mol. Gen. Genet. MGG 163:181-187.

Jahromi, Z. M., Salmanian, A. H., Rastgoo, N. and Arbabi, M. 2009. Isolation of BNYVV coat protein-specific single chain Fv from a mouse phage library antibody. Hybridoma 28:305313.

Lennefors, B.-L., Savenkov, E. I., Bensefelt, J., Wremerth-Weich, E., van Roggen, P., Tuvesson, S., Valkonen, J. P. T. and Gielen, J. 2006. dsRNA-mediated resistance to Beet Necrotic Yellow Vein Virus infections in sugar beet (Beta vulgaris L. ssp. vulgaris). Mol. Breed. 18:313-325.

McGrann, G. R., Grimmer, M. K., Mutasa-Göttgens, E. S. and Stevens, M. 2009. Progress towards the understanding and control of sugar beet rhizomania disease. Mol. Plant Pathol. 10:129-141.

Nickel, H., Kawchuk, L., Twyman, R. M., Zimmermann, S., Junghans, H., Winter, S., Fischer, R. and Prüfer, D. 2008. Plantibody-mediated inhibition of the Potato leafroll virus P1 protein reduces virus accumulation. Virus Res. 136:140-145.

Pavli, O. I., Panopoulos, N. J., Goldbach, R. and Skaracis, G. N. 2010. BNYVV-derived dsRNA confers resistance to rhizomania disease of sugar beet as evidenced by a novel transgenic hairy root approach. Transgenic Res. 19:915-922.

Prins, M., Lohuis, D., Schots, A. and Goldbach, R. 2005. Phage display-selected single-chain antibodies confer high levels of resistance against Tomato spotted wilt virus. J. Gen. Virol. $86: 2107-2113$.

Safarnejad, M. R., Jouzani, G. S., Tabatabaie, M., Twyman, R. M. and Schillberg, S. 2011. Antibody-mediated resistance against plant pathogens. Biotechnol. Adv. 29:961-971.

Schouten, A., Roosien, J., de Boer, J. M., Wilmink, A., Rosso, M.-N., Bosch, D., Stiekema, W. J., Gommers, F. J., Bakker, J. and Schots, A. 1997. Improving scFv antibody expression levels in the plant cytosol. FEBS Lett. 415:235-241.

Schouten, A., Roosien, J., van Engelen, F. A., de Jong, G. A. M. I., Borst-Vrenssen, A. W. M. T., Zilverentant, J. F., Bosch, D., Stiekema, W. J., Gommers, F. J., Schots, A. and Bakker, J. 1996. The C-terminal KDEL sequence increases the expression level of a single-chain antibody designed to be targeted to both the cytosol and the secretory pathway in transgenic tobacco. Plant Mol. Biol. 30:781-793.

Spiegel, H., Schillberg, S., Sack, M., Holzem, A., Nähring, J., 
Monecke, M., Liao, Y.-C. and Fischer, R. 1999. Accumulation of antibody fusion proteins in the cytoplasm and ER of plant cells. Plant Sci.149:63-71.

Tamada, T., Kondo, H. and Chiba, S. 2016. Genetic diversity of beet necrotic yellow vein virus. In: Rhizomania, eds. by E. Biancardi and T. Tamada, pp. 109-131. Springer, Berlin/Heidelberg, Germany.

Tavladoraki, P., Benvenuto, E., Trinca, S., De Martinis, D., Cattaneo, A. and Galeffi, P. 1993. Transgenic plants expressing a functional single-chain Fv antibody are specifically protected from virus attack. Nature 366:469-472.

Valentin, C., Dunoyer, P., Vetter, G., Schalk, C., Dietrich, A. and Bouzoubaa, S. 2005. Molecular basis for mitochondrial localization of viral particles during Beet necrotic yellow vein virus infection. J. Virol. 79:9991-10002.

Villani, M. E., Roggero, P., Bitti, O., Benvenuto, E. and Franconi, R. 2005. Immunomodulation of cucumber mosaic virus infection by intrabodies selected in vitro from a stable single- framework phage display library. Plant Mol Biol. 58:305-316. Weigel, D. and Glazebrook, J. 2009. Dellaporta miniprep for plant DNA isolation. Cold Spring Harb. Protoc. 2009:pdb. prot5178.

Yajima, W., Verma, S. S., Shah, S., Rahman, M. H., Liang, Y. and Kav, N. N. V. 2010. Expression of anti-sclerotinia scFv in transgenic Brassica napus enhances tolerance against stem rot. New Biotechnol. 27:816-821.

Zare, B., Niazi, A., Sattari, R., Aghelpasand, H., Zamani, K., Sabet, M. S., Moshiri, F., Darabie, S., Daneshvar, M. H., Norouzi, P., Kazemi-Tabar, S. K., Khoshnami, M. and Malboobi, M. A. 2015. Resistance against rhizomania disease via RNA silencing in sugar beet. Plant Pathol. 64:35-42.

Zimmermann, S., Schillberg, S., Liao, Y.-C. and Fisher, R. 1998. Intracellular expression of TMV-specific single-chain FV fragments leads to improved virus resistance in shape Nicotiana tabacum. Mol. Breed. 4:369-379. 